Environment, Biodiversity \& Soil Security
(EBSS)
http://jenvbs.journals.ekb.eg//

\title{
Integrated Approaches towards Ameliorating A Saline Sodic Soil and Increasing The Dry Weight of Barley Plants Grown Thereon
}

\author{
Ihab M. Farid", Abo-El-Nasr H. Abdel-Hameed, Esraa A.M. Abd El-Aty, \\ Mohamed H.H. Abbas* and Maha Ali \\ Soils and Water Dept., Fac. of Agriculture, Benha Univ., Egypt
}

\begin{abstract}
OIL salinization and water scarcity are among the major threats affecting crop productivity

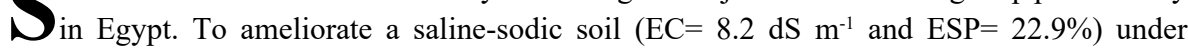
no-leaching conditions, a greenhouse experiment was conducted, including three factors (1: Arthrospira platensis bio-inoculant with two treatments (non-inoculated and inoculated seeds), 2: phosphogypsum with three rates (non, $50 \%$ and 100 of the gypsum requirements and 3: compost with three rates (none, 7.5 and $15 \mathrm{~g} \mathrm{~kg}^{-1}$ ) to evaluate their efficiencies on increasing barley plants grown on such a soil, on one hand, and minimizing soil deterioration in terms of soil EC and ESP., on the other hand. After 75 days of incubation, Arthrospira platensis increased significantly soil EC values, while decreased soil ESP. This inoculant also increased $\mathrm{P}$ and $\mathrm{K}$ uptake by plants while recorded no significant effect on barley dry weight. For soils treated with either compost or phosphogypsum, their highest rates decreased significantly soil ESP and, at the same time, caused significant increases in barley dry weights. Furthermore, these two amendments increased significantly NPK availability ; consequently, their uptake by plants. Generally, phosphogypsum seemed to be more efficient in minimizing the negative implications of no leaching conditions on chemical characteristics than did the compost treatment investigated. Combined amendments seemed to be more efficient than the single ones on improving soil characteristics and increasing plants grown thereon, especially the triple applications which reduced soil ESP by more than 50\%, while increased barley dry-weight by approximately $40 \%$. In conclusion, the integrated treatments are recommended to raise barley productivity grown on salt affected-soils under no leaching conditions; while lessen further soil degradation.
\end{abstract}

Keywords: Saline-sodic soil, Arthrospira platensis, Phosphogypsum; Compost; Barley plants.

\section{Introduction}

Salinization is one of the major threats of soil sustainability in the world (Masoud et al., 2019), especially in arid and semi-arid areas (Rousk et al., 2011; Abou Samra, and Ali, 2018; Mahdavi and Fujimaki, 2019). In Egypt, the stressed conditions of soil salinization has grown up (ElRamady et al., 2019a; El-Akhdar et al., 2019; Negm et al. 2019) to represent about $46 \%$ of the total Nile Delta zone (El-Ramady et al., 2019b). This situation is associated with water scarcity problems (Ouda and Zohry, 2020). Thus, the main challenge of the Egyptian farmers is to grow up salt-tolerant plants under such saline and alkaline conditions and also to manage the ameliorating inputs to lessen further soil deterioration while sustaining soil productivity. It is thought that application of gypsum might not be the optimum choice to ameliorate saline-sodic soils without considering suitable amounts of water to leach out salts away from the rhizosphere (Wang et al., 2019). Also, organic amendments may retain salts against leaching; hence, increase salt stress conditions in soils (Wang et al., 2019). Accordingly, four integrated strategies were tested, in this study, for ameliorating a saline sodic soil without considering irrigation

\footnotetext{
${ }^{*}$ Corresponding email:Mohamed.abbas@fagr.bu.edu.eg

\#ebah.farid@fagr.bu.edu.eg

Received 21/03/2020; Accepted 29/04/2020

DOI: $10.21608 /$ jenvbs.2020.12912.1086

C2020 National Information and Documentation Center (NIDOC)
} 
requirements. The first one is based on the dual application of phosphogypsum and compost. In this concern, calcium (in phosphogypsum) is a low-cost amendment (Makoi and Verplancke, 2010) that can substitute exchangeable sodium; hence reduce the sodicity hazards in soil (Cao et al., 2019). Moreover, phosphogypsum is highly solule in water and its physiological effect is acidic (Elloumi et al., 2015) and this probably makes phosphogypsum more effective than ordinary gypsum in ameliorating saline-sodic soils (Abd El-Fattah, 2014). On the other hand, application of organic amendments is thought to encourage the downward movement of Na-salts away from the rhizosphere (Li et al., 2019a) while, excess calcium salts might prefer to bind to the carboxylic groups of the organic amendment (AduseiGyamfi et al., 2019). This may; in turn, decrease both soil EC and ESP, while improves the release of some nutritive elements upon this organic amendment decomposition (El-Naqm etal.,2019); consequently increases plant grown thereon (Amer et al., 2020). Another integrated amelioration technique is through amending the saline-sodic soil with phosphogypsum +cyanobacteria. According to this approach, soil sodicity is reduced with the application of phosphogypsum, while the bio-inoculants can improve the growth of plants under biotic stresses probably through increasing the uptake of soil K (Selem, 2019). Moreover, cyanobacteria may fix atmospheric N (Murukesan et al., 2019) and; therefore, increase its uptake by plants (Shahane et al., 2019). This combination can probably decrease sodicity (ESP) with slight

TABLE 1. Physicochemical characteristics of the investigated soil

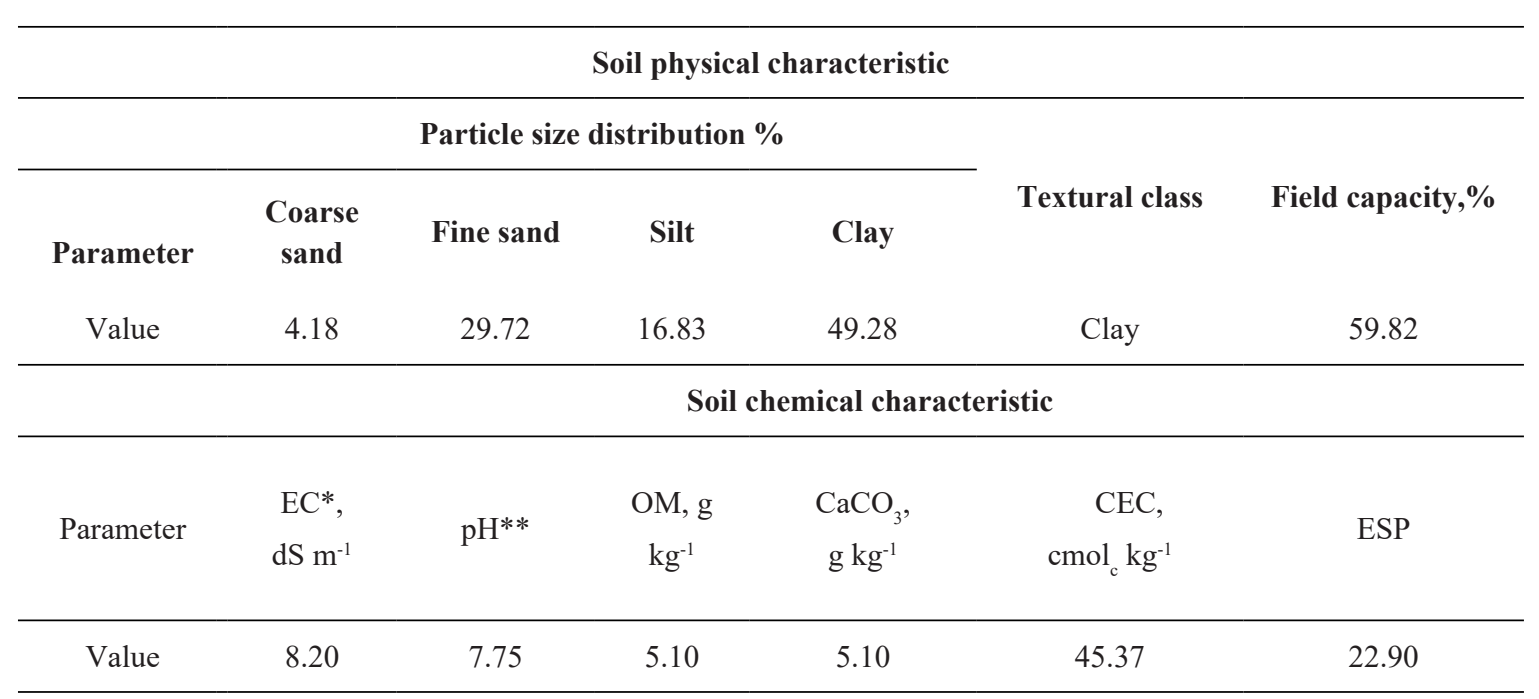

EC*: determined in soil paste extract; $\mathrm{pH}^{* *}$ determined in soil:water suspension prepared at

a rate of 1:2.5; OM: organic matter content in soil; CEC: cation exchange capacity

Env. Biodiv. Soil Security Vol. 4 (2020) increase NPK uptakes as well as the biomass of the grown plants. Combination between the organic amendments and cyanobacteria is the third tested integrated strategy that can be applied for the remediation of saline-sodic soils. According to this combination, cyanobacteria can degrade this amendment to get its needs of carbon (Fuchsman et al., 2019). Therefore this dual application can probably increase the efficiency of each other in ameliorating salt-affected soils by decreasing soil EC and ESP, increasing the availability of NPK and their uptakes by plants with a positive effect on the plant growth. We believe that the combination among cyanobacteria, organic residues and phosphogypsum may have a further superior effect than the single amendments did on decreasing soil EC and ESP while increasing the availability and uptake of NPK by barley plants; thus increase their growths. This study aims to investigate the potentiality of using Arthrospira platensis (cyanobacteria), compost and phosphogypsum either solely or in combinations under no leaching conditions to increase the productivity of saltaffected soils on one hand and lessen further soil deterioration in terms of soil EC and ESP on the other hand.

\section{Materials and Methods}

\section{Materials of study}

Surface soil samples $(0-30 \mathrm{~cm})$ were collected from Sahl El-Hussainia, Sharqia Governorate, Egypt. These samples were analyzed for their physical and chemical characteristics as outlined by Klute (1986) and Sparks et al. (1996). Selected physicochemical characteristics of the investigated soil are presented in Table 1. or no significant effect on soil EC. Also, it can 
Cyanobacteria (Arthrospira platensis HSSASE5, version KT277788) was obtained from Soil, Water \& Environment Research Institute, Giza (Egypt). Seeds of barley (Hordeum vulgare L., Giza 132) were obtained from the National Research Centre, Egypt. Half weight of barley was mixed thoroughly for thirty minutes with the Arthrospira platensis suspension before the cultivation process, while the second half was left without inoculation. Phosphogypsum (88\% purity) was obtained from El-Araby Company (Egypt). Compost was kindly obtained from the Faculty of Agriculture (Benha University) and it was characterized with $\mathrm{pH}, \mathrm{EC}$, moisture, bulk density, organic carbon, $\mathrm{C} / \mathrm{N}$ ratio, Total $\mathrm{P}$ and Total $\mathrm{K}$ of $7.42,6.92 \mathrm{dS} \mathrm{m}^{-1}, 11.37 \%, 0.64 \mathrm{~g} \mathrm{~cm}^{-3}, 42.86$ $\mathrm{g} \mathrm{kg}^{-1}, 12.76 / 1,0.80 \mathrm{~g} \mathrm{~kg}^{-1}$ and $10.38 \mathrm{~g} \mathrm{~kg}^{-1}$, respectively. $\mathrm{pH}$ and $\mathrm{EC}$ were determined in 1:5 (compost: water) suspension.

\section{The greenhouse experiment}

The experiment contained eighteen treatments in triplicates resulted from the different combinations of Arthrospira platensis, phosphogypsum and compost. These treatments were inoculation with Arthrospira platensis at two rates $(0=-B$ and inoculated $=$ $+B$ ), phosphogypsum at three rates $\left[9 \mathrm{~g} \mathrm{~kg}^{-1}\right.$ (equivalent to $100 \%$ of the phosphogypsum requirements $=\mathrm{G}_{100}$ ), $4.5 \mathrm{~g} \mathrm{~kg}^{-1}$ (equivalent to $50 \%$ of the phosphogypsum requirements $=$ $\mathrm{G}_{50}$ ) and $0 \mathrm{~g} \mathrm{~kg}^{-1}=\mathrm{G}_{0}$ (the non-amended control treatment)] and compost at three different rates $\left(0,7.5\right.$ and $15 \mathrm{~g} \mathrm{~kg}^{-1}$ (based on recommendations of previous researches).

Soil samples were mixed thoroughly with the abovementioned amendments then packed in plastic pots $(20 \mathrm{~cm}$ diameter $\times 17.5 \mathrm{~cm}$ depth). The experimental pots were filled further $3 \mathrm{~kg}$ soil. These pots were arranged in a complete randomized design under the greenhouse conditions. Some pots were cultivated with inoculated seeds (10 seeds per pot), while other pots were cultivated with barley seeds without Arthrospira platensis inoculation. All pots received NPK fertilizers at the recommended rates of the Egyptian Ministry of Agriculture (equivalent to $100 \mathrm{~kg} \mathrm{~N}, 40 \mathrm{~kg} \mathrm{P}$ and $60 \mathrm{~kg} \mathrm{~K} \mathrm{ha}{ }^{-1}$ in the forms of the following fertilizers: urea, calcium superphosphate and potassium sulphate, respectively). Plants were irrigated with tab water every 5 days to bring and maintain soil moisture at $80 \%$ of its water holding capacity. After germination, plants were thinned to five plants per pot and all pots were kept under greenhouse conditions for 75 days. Afterwards, the aerial parts of the grown plants were cut and dried at $60-70{ }^{\circ} \mathrm{C}$ for 72 h. Also, soil samples were collected from the rhizosphere of the grown plants.

\section{Plant and soil analyses}

Dried plant materials were cut, crushed and equivalent masses of $0.5 \mathrm{~g}$ were digested in a mixture of $\mathrm{H}_{2} \mathrm{SO}_{4}$ and $\mathrm{H}_{2} \mathrm{O}_{2}(1: 1)$ as outlined by Lowther (1980) then transferred volumetrically using deionized water to $50 \mathrm{~mL}$ conical flasks. Total contents of NPK were measured according to the protocol of Page et al. (1982); total-N by micro-Kjeldahel apparatus, total-P spectrophotometrically (SM1600 UVVIS Spectrophotometer) and total $\mathrm{K}$ and $\mathrm{Na}$ by flame photometer (Jenway model PFP7 flame photometer). Soil $\mathrm{pH}$ was measured in 1:2.5 (soil: water) suspension by $\mathrm{pH}$ meter (JENCO 6173). Soil EC was determined in the soil paste extract using EC meter (HANNA EC 215). Available amounts NPK were also determined in soil samples according to Page et al. (1982) i.e., available soil-N was extracted by $\mathrm{K}_{2} \mathrm{SO}_{4}$, then measured by micro Kjelkdahel unit, Olson-extracted-P was determined using Spectrophotometer and ammonium acetate $(1 N$, $\mathrm{pH}$ 7) extracted-K was measured by flame photometer.

\section{Data analysis}

The obtained data were statistically analyzed using PASW Statistics software through the analysis of variance (ANOVA) and Dunken or Tests at 0.05 probability level. The figures were presented using Sigma Plot 10.0.

\section{Results}

Effect of soil amendments on soil EC and ESP

Table 2 indicated that inoculating barley seeds with Arthrospira platensis significantly increased soil EC. Such an unexpected result was detected in soils that did not receive any amendment as well as those received zero or $7.5 \mathrm{~g}$ compost $\mathrm{kg}^{-1}$ soil. However, in the soil amended with $15 \mathrm{~g}$ compost $\mathrm{kg}^{-1}$ and inoculated with this bio-agent, no significant variations in the measured values of soil EC were noticed. In the case of phosphogypsum, its application at a rate of $9 \mathrm{~g} \mathrm{~kg}^{-1}$ had no significant effect on soil EC. However, its application at the recommended rate $\left(9 \mathrm{~g} \mathrm{~kg}^{-1}\right)$ significantly decreased soil EC. 
Inoculating barley seeds with Arthrospira platensis markedly decreased soil ESP (Table 2). Likewise, amending soil with either phosphogypsum or compost significantly diminished soil ESP. Such reductions seemed to be more significant with increasing rates of these amendments in soil. Concerning the combination among the studied treatments, it seemed that the highest reduction in soil ESP was attained due to the dual application of $9 \mathrm{~g}$ phosphogypsum $+15 \mathrm{~g}$ compost $\mathrm{kg}^{-1}$ (in presence of Arthrospira platensis inoculum). This treatment decreased soil ESP by more than $50 \%$ of its initial value. On the other hand, the recorded ESP value in soil amended with $15 \mathrm{~g}$ compost $\mathrm{kg}^{-1}$ was lower than the corresponding one recorded in soil amended with $7.5 \mathrm{~g}$ compost $\mathrm{kg}^{-1}$ in presence of both Arthrospira platensis inoculums and either of 0 or $4.5 \mathrm{~g} \mathrm{~kg}^{-1}$ phosphogypsum.
Effect of soil amendments on barley dry weight Inoculating plants with Arthrospira platensis and application of $7.5 \mathrm{~g}$ compost $\mathrm{kg}^{-1}$ had no significant effect on barley dry weight (Fig 1). However, significant increases occurred in plant dry weight owing to application of the organic compost at a rate of $15 \mathrm{~g} \mathrm{~kg}^{-1}$. In soils amended with phosphogypsum, significant increases in plant dry weights were also noticed, especially with increasing rate of application of this amendment. Generally, phosphogypsum application seemed to be more efficient in minimizing the implications of soil no leaching conditions on salinity and sodicity than did the compost addition. The combination between the investigated three factors (bio $\times$ organic $\times$ chemical) revealed that the highest increases in plant dry weight were achieved in soils amended with 9 g phosphogypsum" irrespective of either the rate of applied compost or inoculation with Arthrospira platensis.

TABLE 2. Soil EC and soil ESP (mean \pm SD) as affected by amending a saline-sodic soil with Arthrospira platensis, compost and phosphogypsum either solely or in combinations

\begin{tabular}{|c|c|c|c|c|c|c|c|c|c|}
\hline \multirow{2}{*}{$\begin{array}{c}\text { Compost } \\
\text { (C) }\end{array}$} & \multirow{2}{*}{$\begin{array}{c}\text { Bio- } \\
\text { treat } \\
\text { (B) }\end{array}$} & \multicolumn{4}{|c|}{ Phosphogypsum, $\mathrm{g} \mathrm{kg}^{-1}(\mathrm{G})$} & \multicolumn{4}{|c|}{ Phosphogypsum, $\mathrm{g} \mathrm{kg}^{-1}(\mathrm{G})$} \\
\hline & & 0 & 4.5 & 9 & mean & 0 & 4.5 & 9 & mean \\
\hline & & \multicolumn{4}{|c|}{ Soil EC ( $\left.\mathrm{dS} \mathrm{m}^{-1}\right)$} & \multicolumn{4}{|c|}{ Soil ESP } \\
\hline \multirow{3}{*}{$\begin{array}{c}0 \\
\mathrm{~g} \mathrm{~kg}^{-1}\end{array}$} & $-B i o$ & $8.90 \pm 0.56$ & $6.85 \pm 0.43$ & $6.74 \pm 0.61$ & 7.50 & $18.35 \pm 1.64$ & $11.21 \pm 0.93$ & $10.03 \pm 0.95$ & 13.20 \\
\hline & + Bio & $9.19 \pm 0.73$ & $9.79 \pm 0.33$ & $9.00 \pm 0.72$ & 9.33 & $16.76 \pm 0.55$ & $9.43 \pm 0.73$ & $7.10 \pm 0.63$ & 11.09 \\
\hline & mean & 9.05 & 8.32 & 7.87 & 8.41 & 17.55 & 10.32 & 8.56 & 12.14 \\
\hline \multirow{3}{*}{$\begin{array}{c}7.5 \\
\mathrm{~g} \mathrm{~kg}^{-1}\end{array}$} & $-B i o$ & $6.24 \pm 0.56$ & $7.61 \pm 0.45$ & $6.34 \pm 0.53$ & 6.73 & $11.73 \pm 1.10$ & $12.84 \pm 0.89$ & $12.74 \pm 0.69$ & 12.44 \\
\hline & + Bio & $9.04 \pm 0.83$ & $9.73 \pm 0.71$ & $9.17 \pm 0.84$ & 9.31 & $9.36 \pm 0.78$ & $10.26 \pm 0.93$ & $11.97 \pm 0.89$ & 10.53 \\
\hline & mean & 7.64 & 8.67 & 7.76 & 8.01 & 10.54 & 11.55 & 12.36 & 11.81 \\
\hline \multirow{3}{*}{$\begin{array}{c}15 \\
\mathrm{~g} \mathrm{~kg}^{-1}\end{array}$} & $-B i o$ & $8.52 \pm 0.77$ & $9.70 \pm 0.82$ & $10.38 \pm 1.04$ & 9.53 & $11.64 \pm 0.94$ & $11.97 \pm 0.92$ & $9.59 \pm 0.84$ & 11.07 \\
\hline & + Bio & $9.71 \pm 0.94$ & $8.90 \pm 0.82$ & $8.89 \pm 0.78$ & 9.20 & $10.94 \pm 0.82$ & $11.24 \pm 0.98$ & $9.01 \pm 0.60$ & 10.39 \\
\hline & mean & 9.12 & 9.3 & 9.64 & 9.34 & 11.29 & 11.61 & 9.30 & 10.72 \\
\hline \multicolumn{2}{|c|}{ Grand mean } & 8.60 & 8.76 & 8.42 & & 13.13 & 11.16 & 10.07 & \\
\hline \multicolumn{10}{|c|}{ Means of Compost } \\
\hline & $-B i o$ & 7.89 & 8.05 & 7.82 & 7.92 & 13.91 & 12.01 & 10.79 & 12.23 \\
\hline & + Bio & 9.31 & 9.47 & 9.02 & 9.27 & 12.35 & 10.31 & 9.36 & 10.67 \\
\hline \multicolumn{2}{|c|}{$\operatorname{LSD}_{(0.05)}$} & \multicolumn{4}{|c|}{$\begin{array}{c}\mathrm{C}=0.84, \mathrm{~B}=0.69, \mathrm{G}=\mathrm{ns}, \mathrm{C} \times \mathrm{B}=1.19, \\
\mathrm{~B} \times \mathrm{G}=\mathrm{ns}, \mathrm{C} \times \mathrm{G}=\mathrm{ns}, \mathrm{C} \times \mathrm{B} \times \mathrm{G}=2.06\end{array}$} & \multicolumn{4}{|c|}{$\begin{array}{c}\mathrm{C}=0.40, \mathrm{~B}=0.32, \mathrm{G}=0.40, \mathrm{C} \times \mathrm{B}=0.56, \\
\mathrm{~B} \times \mathrm{G}=\mathrm{ns}, \mathrm{C} \times \mathrm{G}=0.69, \mathrm{C} \times \mathrm{B} \times \mathrm{G}=0.97\end{array}$} \\
\hline
\end{tabular}

$-B$ : without inoculation, $+B$ : with inoculation. 

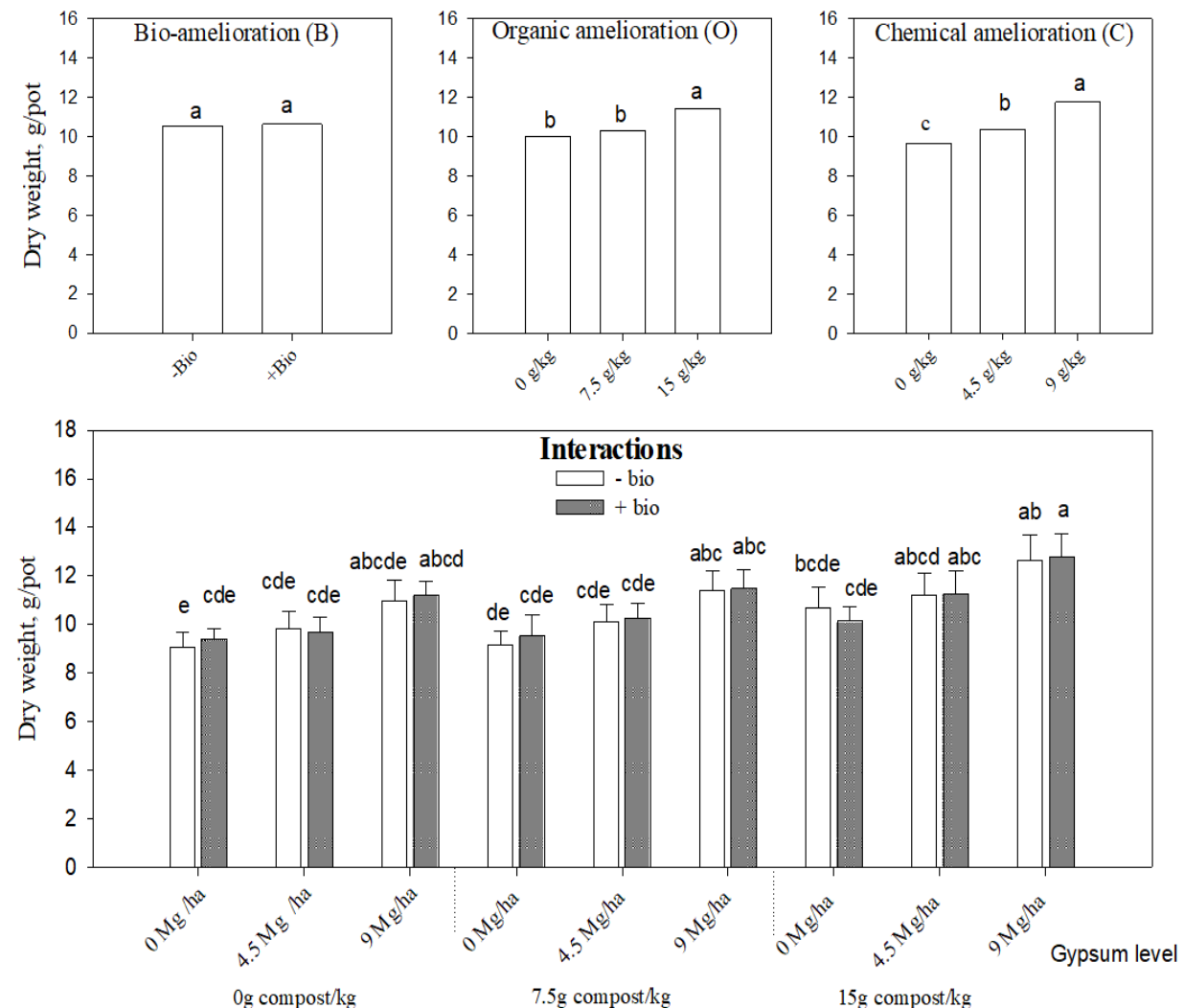

Fig. 1. Barley dry weight $(\operatorname{mean} \pm$ SD) as affected by amending a saline-sodic soil with Arthrospira platensis, compost and phosphogypsum either solely or in combinations. Similar letters indicate no significant variations.

Effect of soil amendments on nutrient uptake by barley plants

$N$ - uptake

Soaking seeds in Arthrospira platensis suspension recorded no momentous effect on $\mathrm{N}$-uptake by plants. However, amending the investigated soil with compost significantly improved N uptake (Table 3). Such increases were more pronounced with increasing the rate of applied compost. Likewise, amending the investigated soil with phosphogypsum increased significantly N-uptake by plants. Interactions among these three factors were also of significant effect on barley dry weight. In this concern, the highest increases in $\mathrm{N}$-uptake were achieved due to amending soil with both " 15 $\mathrm{g}$ compost $+9 \mathrm{~g}$ phosphogypsum $\mathrm{kg}^{-1}$ " where these increases were 3-4 folds higher than the non-amended control treatment.

\section{P-uptake}

Marked increases in P-uptake also occurred in plants inoculated with Arthrospira platensis (Table 3). Likewise, increasing the rate of applied compost or phosphogypsum resulted in concurrent significant increases in P-uptake by barley plants. Generally, the highest uptake of $\mathrm{P}$ occurred by the plants inoculated with Arthrospira platensis and amended with either "15 g compost $+9 \mathrm{~g}$ phosphogypsum $\mathrm{kg}^{-1}$ " or “ $15 \mathrm{~g}$ compost $+4.5 \mathrm{~g}$ phosphogypsum $\mathrm{kg}^{-1}$ " with no significant variations between these two treatments.

\section{K-uptake}

Important rises occurred in K-uptake by barley plants owing to soaking its seeds in Arthrospira platensis suspension. Likewise, amending soil with the organic amendment (compost) increased significantly the uptake of $\mathrm{K}$ by plants. Such increases were more pronounced with increasing the rate of applied compost. Although, the application of $4.5 \mathrm{~g}$ phosphogypsum $\mathrm{kg}^{-1}$ increased significantly the uptake of $\mathrm{K}$ by plants; however, increasing the dose of its application (i.e., $9 \mathrm{~g} \mathrm{~kg}^{-1}$ ) reduced significantly this uptake. The attained values of K-uptake by barley plants at this level of phosphogypsum were still significantly higher than that attained for the control treatment. 


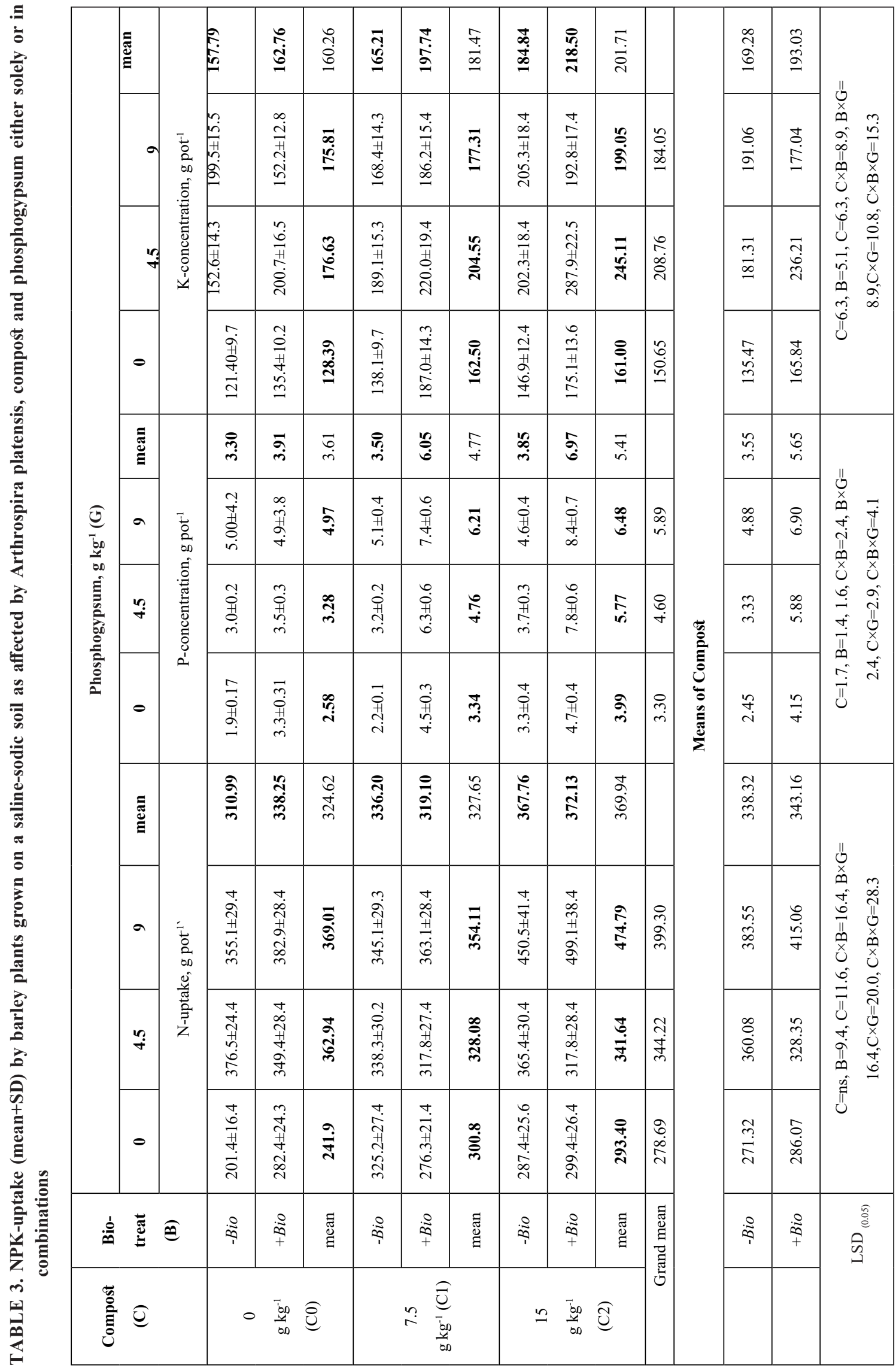


Na-uptake by barley plants

Figure 2 indicated that soaking seeds with Arthrospira platensis significantly decreased Nauptake by more than $22 \%$. Likewise, amending the studied soil with phosphogypsum, decreased significantly the uptake of $\mathrm{Na}$ by plants. On the other hand, application of compost significantly increased the uptake of $\mathrm{Na}$ by barley plants. Generally, the highest reductions in Na-uptake by barley plants took place when inoculated plants grown on soils amended with $9 \mathrm{~g}$ phosphogypsum $+0 \mathrm{~g}$ compost $\mathrm{kg}^{-1}$ (>33\% reduction in Na uptake when compared with the non-amended control treatment).

Effect of soil amendments on NPK availability in soil

Table 4 indicates that $\mathrm{P}$ and $\mathrm{K}$ availability in soil markedly enhanced owing to plant inoculation with Arthrospira platensis; while this inoculant recorded no significant effect on soil available-N content. Application of compost also showed positive effects on NPK availability in the soil, especially with increasing the rate of applied compost.

Moreover, the application of phosphogypsum resulted in additional substantial rises in NPK availability in the soil, especially with increasing its level of application. In this concern, soaking seeds in Arthrospira platensis suspension in the presence of both $9 \mathrm{~g}$ phosphogypsum $+15 \mathrm{~g}$ compost $\mathrm{kg}^{-1}$ recorded approximately 1.5 folds higher available-N than the control. Also, this treatment caused 2.35 and 1.3 folds higher than the non-inoculated and non-amended soils for both available $\mathrm{P}$ and $\mathrm{K}$ contents, respectively.

Biomass of barley as affected by soil EC, ESP and nutrients availability and uptake

To investigate such relationships, multiple correlations were conducted and the obtained results are presented in Table 5. These results indicated that barley biomass was correlated significantly and positively with NPK-uptake by plants. Such uptakes correlated significantly with the available indices of these nutrients in soil. On the other hand, plant biomass significantly and negatively influenced by Na-uptake; however, correlated positively and significantly with soil salinity. This might indicate that barley is more sensitive to $\mathrm{Na}$ than its response to soil salinity. Although, Arthrospira platensis and phosphogypsum were used to ameliorate such a soil; however, these amendments might raise; on the other hand, soil salinity. In spite of that, these two conditioners improved soil physical conditions and; hence, decreased soil ESP. Thus, a significant positive correlation was detected between barley biomass and soil salinity.
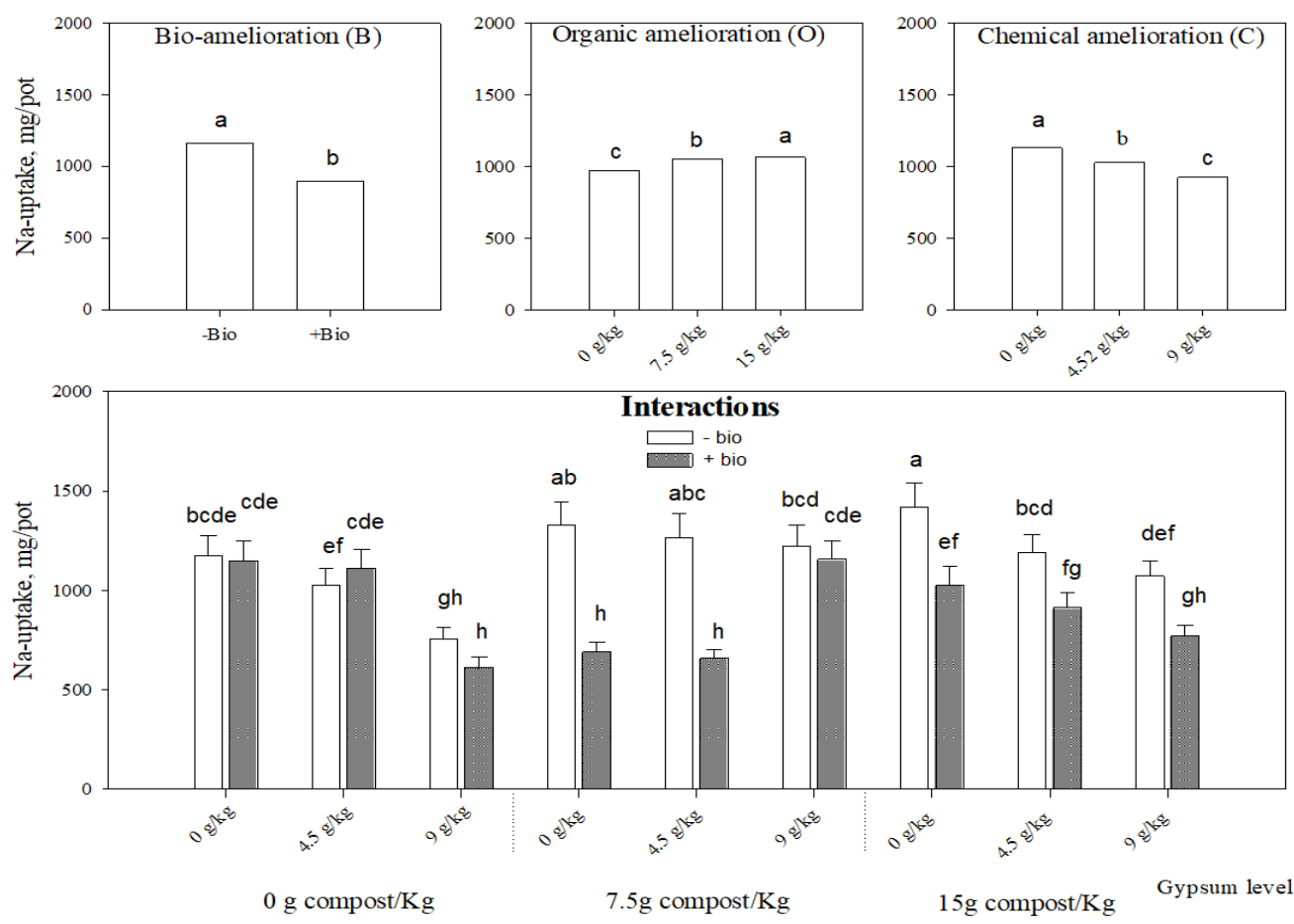

Fig. 2. Na-uptake (mean+SD) by barley plants as affected by Arthrospira platensis, compost and phosphogypsum either solely or in combinations. Mean with the same letter within columns are not significantly different at $P=0.05$ 


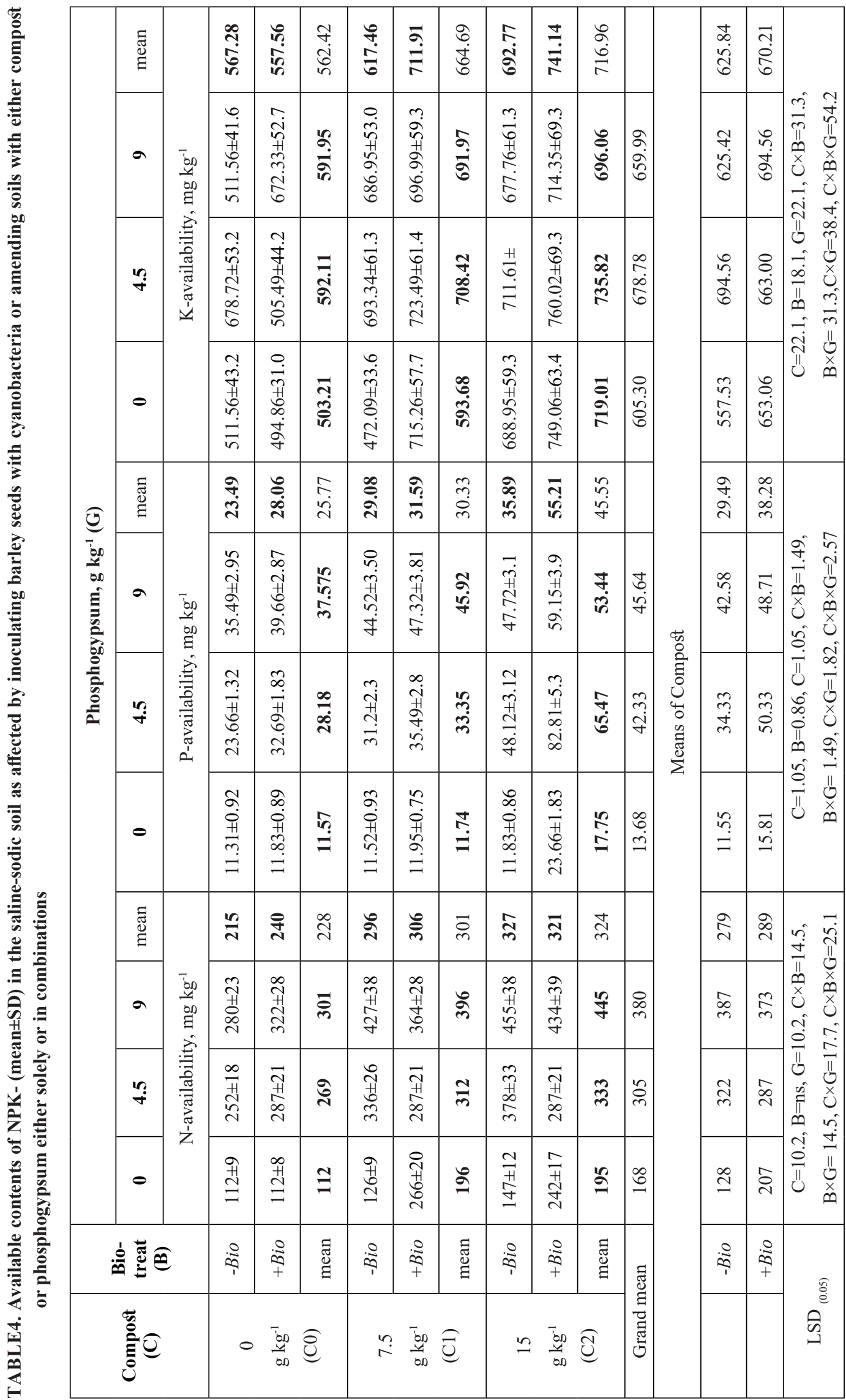

Env. Biodiv. Soil Security Vol. 4 (2020) 
TABLE 5. Correlation relationships between soil chemical characteristics and plants grown thereon.

\begin{tabular}{|c|c|c|c|c|c|c|c|c|c|c|}
\hline & & \multirow[b]{2}{*}{ EC } & \multirow[b]{2}{*}{ ESP } & \multirow{2}{*}{$\begin{array}{c}\text { Plant } \\
\text { biomass } \\
\text { N-uptake }\end{array}$} & \multicolumn{4}{|c|}{ Plant uptake } & \multicolumn{2}{|c|}{ Nutrient availability } \\
\hline & & & & & P-uptake & K-uptake & $\begin{array}{c}\text { Na- } \\
\text { uptake }\end{array}$ & Av-N & Av-P & Av-K \\
\hline \multicolumn{11}{|c|}{$\mathrm{EC}$} \\
\hline \multirow{6}{*}{$\begin{array}{l}\text { Plant } \\
\text { uptake }\end{array}$} & ESP & -0.064 & & & & & & & & \\
\hline & yield & $0.327^{*}$ & $-0.471^{* *}$ & & & & & & & \\
\hline & N-uptake & 0.103 & $-0.570^{* *}$ & $0.831^{* *}$ & & & & & & \\
\hline & P-uptake & 0.260 & $-0.425^{* *}$ & $0.481^{* *}$ & $0.510^{* *}$ & & & & & \\
\hline & K-uptake & $0.336^{*}$ & $-0.379^{* *}$ & $0.324^{*}$ & $0.333^{*}$ & $0.677^{* *}$ & & & & \\
\hline & Na-uptake & -0.169 & $0.584^{* *}$ & -0.184 & -0.206 & $-0.501^{* *}$ & $-0.321^{*}$ & & & \\
\hline \multirow{3}{*}{$\begin{array}{c}\text { Nutrient } \\
\text { availability }\end{array}$} & $\mathrm{Av}-\mathrm{N}$ & 0.187 & $-0.503^{* *}$ & $0.767^{* *}$ & $0.777^{* *}$ & $0.596^{* *}$ & $0.528^{* *}$ & -0.247 & & \\
\hline & Av-P & 0.149 & $-0.311^{*}$ & $0.438^{* *}$ & $0.529^{* *}$ & $0.828^{* *}$ & $0.796^{* *}$ & -0.259 & $0.632^{*}$ & \\
\hline & Av-K & 0.190 & -0.156 & $0.735^{* *}$ & $0.337^{*}$ & $0.540^{* *}$ & $0.379^{* *}$ & 0.019 & $0.316^{*}$ & $0.434^{* *}$ \\
\hline
\end{tabular}

\section{Discussion}

Soil salinization is one of the major problems in Egypt which accounts for $46 \%$ of the total Nile Delta zone. This situation is associated with water scarcity problem and poor agricultural practices. Under such conditions, the capillary rise of water and salts occur (Chávez-García and Siebe, 2019) and consequently salts accumulate on soil surfaces forming salt affected soils. These soils should; therefore, undergo appropriate amelioration in order to minimize their negative consequences on food security (Panda and Parida, 2019). Accordingly, three integrated amelioration techniques i.e., bio-, organo- and chemical were used to ameliorate a salinesodic soil $\left(\mathrm{EC}=8.2 \mathrm{dSm}^{-1}\right.$ and $\left.\mathrm{ESP}=22.90\right)$, either solely or in combinations in absence of leaching requirements. The mode of action of the investigated amendments will be presented below. It is thought that soil salinization causes nutrient imbalance in plants (Kaya et al., 2001 and Munns and Tester, 2008). Thus, the availability and uptake of NPK by grown plants were also considered in the current study; in addition to Nauptake which was a matter of concern herein.

Arthrospira platensis (cyanobacteria) for reclamation of saline-sodic soil

Results indicate that soil EC increased significantly when seeds of barley were inoculated with Arthrospira platensis before cultivation in soil and amended with either zero or $7.5 \mathrm{~g}$ compost $\mathrm{kg}^{-1}$. However, in presence of $15 \mathrm{~g}$ compost $\mathrm{kg}^{-}$ ${ }^{1}$, soil EC did not vary significantly between the inoculated and non-inoculated treatments. The following two parallel scenarios might take place in soil: (1) this halophytic organism preserves some salts in the rhizosphere to maintain its activity (mechanism I). The findings of Apte and Thomas (1997) support this assumption as they found that the removal of surface top soil (rich in cyanoacteria) reduced significantly soil EC by approximately $26-38 \%$. Thus, it can be deduced that "the elevated salinity levels might be an obligate to this symbiotic association" (Green et al., 2017). The another scenario indicates that application of organic matter, particularly at its highest rate, stimulated the activities of cyanobacteria enzymes (Jha et al., 2004) which could absorb $\mathrm{Na}^{+}$as an essential nutrient and cannot be replaced by other nutrients (Thomas et al., 1984) (mechanism II). Moreover, cyanobacteria improve additionally soil aggregation and stability (Nisha et al., 2018) besides encouraging further aggregation of soil particles through precipitation of organic matter from cyanobacteria (Singh et al., 2016a; Singh and Singh, 2018). These aggregates might consecutively increase the downward movement of salts from the rhizosphere (mechanism III), especially Na salts (Li et al., 2019b). The results of study did not contradict, therefore, the findings of Eletr et al. (2013) who indicated that cyanobacteria decreased significantly soil EC. This is because 
the initial soil EC in their study was relatively high (about $11 \mathrm{dS} \mathrm{m}^{-1}$ ) while this bio-agent probably retained relatively lower concentrations of soluble salts within its rhizosphere.

Soaking seeds in Arthrospira platensis suspension also decreased significantly soil ESP. The following mechanisms might also take place owing to seeds coating with Arthrospira platensis: (1) the organic acids released by this microbe decreased soil pH (Pandey et al., 2005); hence, increased the solubility of less-soluble Casalts in soil (Kamel et al., 2016), (2) cyanobacteria released extracellular polysaccharides that chelated cations e.g. calcium (Nisha et al., 2018); hence, increased its capability to substitute sorbed $\mathrm{Na}$ on clay minerals, (3) cyanobacteria produce "specific fatty acids, sucrose- and osmoticstress-induced proteins" (Singh and Dhar, 2010). These mechanisms may integrate to improve soil aggregation and increase the infiltration of leaching water (carrying out soluble $\mathrm{Na}$ ) away from the rhizosphere (Anand et al., 2015).

Inoculating plants with cyanobacteria is a widely used practice to increase plant tolerance against salinity stresses because this symbiotic bacterium (Wein et al., 2019) produces antioxidative enzymes (Tang et al., 2007) that can survive under extreme conditions and; therefore, can be used for reclaiming saline-sodic soils (Singh and Dhar, 2010). However, results obtained herein, did not support the effectiveness of the sole application of cyanobacteria for improving the dry weight of barley plants grown on such a saline-sodic soil (under study). Probably the positive implications of cyanobacteria imposed upon their integration with the other applied amendments. On the other hand, significant increases in $\mathrm{P}$ and $\mathrm{K}$ uptake occurred in plants inoculated with Arthrospira platensis. This might take place because cyanobacteria synthesized chelator(s) (Du et al., 2019) and/or organic acids that mobilize the different insoluble forms of inorganic phosphate (Singh et al., 2016a). The synthesized chelators for $\mathrm{Ca}^{2+}$ shift the equation shown hereafter towards further increases in the solubility of $\mathrm{P}$ in soil as mentioned by Cameron and Julian (1988) and Singh et al. (2016b).

$$
\mathrm{Ca}_{10}(\mathrm{OH})_{2}\left(\mathrm{PO}_{4}\right)_{6} \rightarrow 10 \mathrm{Ca}^{2+}+2 \mathrm{OH}^{-}+6 \mathrm{PO}_{4}^{3-}
$$

Thus, cyanobacteria recycle and enrich soils with soluble-P (Nõges et al., 2008). Moreover, these bacteria are characterized by the cellspecific P-uptake (Fu et al., 2005; Aubriot and
Bonilla, 2012); hence, improved significantly the availability and uptake of $P$ by the grown barley plants. In case of K, cyanobacteria have a relatively efficient $\mathrm{K}^{+}$uptake system under the saline - sodic conditions depending on both proton gradient and ATP (Berry et al., 2003) or through potassium selective channels (Checchetto et al., 2012). These cyanobacteria increased $\mathrm{K}$ availability and its uptake by the grown plants; hence, increased plant tolerance to this abiotic stress (Munns and Tester, 2008; Rady et al., 2018). It also uses this nutrient for the photosynthesis recovery of this bacterium (Qiu et al., 2004). It is worthy to mention that cyanobacteria could absorb $\mathrm{Na}^{+}$as an essential nutrient and cannot be replaced by other nutrients (Thomas et al., 1984). This might, in turn, improve the membrane permeability of the symbiont grown plants e.g. barley (Larbi et al., 2020).

\section{Compost as a potential amendment for reclamation of saline-sodic soil}

The application of compost at its highest rate (15 $\mathrm{g} \mathrm{kg}^{-1}$ ) decreased significantly soil EC and this is probably because: (1) this amendment minimized the activity of some soluble salts (Abdelhafez et al., 2018), besides, it improved soil aggregation (Elcossy et al., 2020) which consequently increased the removing of salts away from the top soil (Abdel-Ati and Eisa, 2015; Kamel et al., 2016; Pavani et al., 2019; Wang et al., 2019). (2) This amendment acts as barriers against capillary rise of water and salts (ChávezGarcía and Siebe, 2019), besides, it may retain soil moisture within the rhizosphere (Bassouny and Abbas, 2019; Menzies Pluer et al., 2020) which may dilute the salinity stresses. (3) This organic amendment also increased the solubility of $\mathrm{Ca}$ salts in soil and this might increase its capability to substitute adsorbed $\mathrm{Na}^{+}$on the clay minerals (Chaganti et al., 2015). Moreover, compost increased the solubility of $\mathrm{CaCO}_{3}$ which dissolved and liberated more $\mathrm{Ca}$ ions to substitute adsorbed $\mathrm{Na}$ on clay minerals (Abdel-Ati and Eisa, 2015). These mechanisms played together in decreasing soil ESP (as presented in Fig 2); thus, reduced the sodic hazards in soil.

It seems that the application of $7.5 \mathrm{~g}$ compost $\mathrm{kg}^{-1}$ soil did not affect the dry weight of barley dry weight); however, its application at a rate of $15 \mathrm{~g}$ $\mathrm{kg}^{-1}$ improved significantly plant dry weight. This positive effect of such applied organic amendment was also detected by Abdel-Ati and Eisa (2015) and may be attributed to the significant increases 
that took place in NPK released to soil upon its decomposition; consequently uptake of these nutritive elements increased by the grown plants. Similar results indicated that $\mathrm{N}$ (Abdelhafez et al., 2017 \& 2018 and El-Akhdar et al., 2018), P and $\mathrm{K}$ availability increased by the grown plants and therefore, their uptake increased in soil amended with compost (Abbas et al., 2011; Farid et al., 2018). Moreover, organic matter probably postponed the crystallization of amorphous calcium phosphate (Lei et al., 2018).

Phosphogypsum as a potential amendment for reclamation of saline-sodic soils

Application of phosphogypsum at a rate of $4.5 \mathrm{~g} \mathrm{~kg}^{-1}$ recorded no significant effect on soil $\mathrm{EC}$; however, its application at a rate of $9 \mathrm{~g} \mathrm{~kg}^{-1}$ decreased significantly soil salinity. Also, this amendment decreased significantly soil ESP, especially with increasing its rate of application. This is because Ca ions (presented as a component of this amendment) replaced adsorbed $\mathrm{Na}$ on the exchange sites of soil minerals (Guo et al., 2006, Farid et al., 2014 and Helmi et al., 2018). Also the calcium ions increased soil aggregation through the cationic bridging (Wuddivira and CampsRoac, 2007 and Amer \& Hashim, 2018) and this might, in turn, increase the downward movement of salts away from the rhizosphere (Syed-Omar and Sumner, 1991), especially $\mathrm{Na}$ ions (Chaganti et al., 2015).

Phosphogypsum effect was also noticeable on dry weights of barley plants grown on the studied saline sodic soil; especially with increasing the rate of its application. This is because the phosphogypsum amendment raised considerably the concentrations of $\mathrm{Ca}^{2+}$ in soil (Amer and Hashim, 2018) which protect plant cell membrane from the hazards of salinity (Misra et al., 2001); beside of the ameliorating effects of this amendment on soil. This considerably increased the total yield of barley grown on such adverse conditions (Amer and Hashim, 2018). Moreover, significant increases in NPK availability occurred in phosphogypsum amended soils Probably, phosphogypsum increased soil hydraulic conductivity (Rasouli et al., 2013) besides, it increased significantly organic $\mathrm{N}$ mineralization (Bailey, 1995); hence, improved $\mathrm{NH}_{4}^{+}$mobility in soil (Favaretto et al., 2012). Accordingly, application of phosphogypsum significantly enhanced the nitrogen use efficiency by crops grown on salt affected soils (Murtaza et al., 2017). It also slows down P loss from soils
(Uusitalo et al., 2012); besides, it decreased soil pH (Murtaza et al., 2017) and this consequently increases P- solubility in soil. The positive effect of phosphogypsum on $\mathrm{K}$ uptake can take place through minimizing the $\mathrm{Na} / \mathrm{K}$ ratio within plants (Khan et al., 1996) while decrease the leakage of $\mathrm{K}^{+}$in parent cells (Swapnil and Rai, 2018). Generally, phosphogypsum application seemed to be more efficient on minimizing the implications of soil salinity and sodicity than the organic compost did.

Integrated amendments as potential tools for reclamation of saline-sodic soils

Four integrated amelioration techniques were highlighted in this study to investigate their positive consequences on improving soil characteristics and plants grown thereon. Generally, the outcomes of dual amendments seemed to be more promising on both soils and plants than the single ones did. (1) The dual application of compost and phosphogypsum recorded further significant reductions in both soil EC and ESP. This combination also improved NPK availability; hence improved their uptake and growth of barley plants beyond those attained for the single treatments. Accordingly, the authors support the first integrated approach. (2) Soaking seeds in Arthrospira platensis together with application of phosphogypsum as a soil amendment also decreased soil EC and ESP, especially upon application of the highest rate of phosphogypsum. Such a technique raised; on the other hand, the available contents of NPK in soil, and improved their uptake by plants. This optimistically resulted in significant increases in the growth of barley plants grown under the saline-sodic conditions. Thus, the authors also encourage using the second integrated approach for ameliorating saline-sodic soils. (3) Inoculating seeds with Arthrospira platensis in presence of compost also recorded positive effects on soil chemical characteristics and plants grown thereon similar to those attained due to the dual application of Arthrospira platensis + phosphogypsum and; therefore, the authors promote the third integrated approach. It is worthy to mention that the combination among the three investigated ameliorating treatments i.e. bio-, organo- and chemical treatments recorded further positive significant effects on soil chemical characteristics and plants grown thereon beyond those attained for the effects of the dual amendments. In this concern, triple combination reduced soil ESP, when applied at their highest 
rates, by more than $50 \%$, while increased barley dry-weight by approximately $40 \%$. Thus, authors recommend the fourth integrated approach.

In conclusion, the above-mentioned results highlighted the positive effects of integrated treatments i.e. Arthrospira platensis, compost and phosphogypsum in dual and triple combinations to raise the productivity of barley plants grown on salt affected soils under no leaching conditions on one hand; while lessening soil degradation in terms of soil EC and ESP on the other hand. However, more investigations are required under field conditions for long time periods to acquire more reliable results.

\section{Acknowledgement}

Authors would like to thank Prof Dr Hassan H. Abbas, Prof Dr Esmat A. Noufal and Dr Ibrahim Mohamed (Soils and Water Department, Faculty of Agriculture, Benha University, Egypt) for their support and assistance while conducting this study

\section{References}

Abbas, M.H.H., Ismael, A.O.A., El-gamal, M. M. and Salem, H.(2011) Integrated effect of mineral nitrogen, bio and organic fertilization on soybean productivity. Egypt. J. Biotechnol. 39, 43-63.

Abd El-Fattah, M.K. (2014) Impact of calcium source on modification of properties of saline-sodic soils. Egypt. J. Soil Sci. 54 (1), 22-33.

Abdel-Ati, A.A.and Eisa, S.S. (2015) Response of barley grown under saline condition to some fertilization treatments. Annal. Agri. Sci. 60, 413421, https://doi.org/10.1016/j.aoas.2015.11.002.

Abdelhafez, A.A., Abbas, M.H.H., Attia, T.M.S., El Bably, W. and Mahrous, S.E. (2018) Mineralization of organic carbon and nitrogen in semi-arid soils under organic and inorganic fertilization. Environ. Technol. Innov. 9, 243-253, https://doi. org/10.1016/j.eti.2017.12.011.

Abdelhafez, A.A., Abbas, M.H.H.and Li, J. (2017) Biochar: The black diamond for soil sustainability, contamination control and agricultural production, In: Engineering Applications of Biochar (WuJang Huang, ed) Intech Open, pp7-27 https://doi. org/10.5772/intechopen.68803.

Abou Samra, R.M. and Ali, R.R. (2018) The development of an overlay model to predict soil salinity risks by using remote sensing and GIS techniques: a case study in soils around Idku Lake,
Egypt. Environ. Monit. Assess. 190, 706. https:// doi.org/10.1007/s10661-018-7079-3

Adusei-Gyamfi, J., Ouddane, B., Rietveld, L., Cornard, J.-P. and Criquet, J. (2019) Natural organic mattercations complexation and its impact on water treatment: A critical review, Water Res 160, 130147. https://doi.org/10.1016/j.watres.2019.05.064.

El-Akhdar, I., Omara, A. and Abdel-Rahman, M. (2018) Intergradation of different fertilizers for sustainable agriculture enhanced growth and yield of wheat (Triticum aestivum L.). Env. Biodiv. Soil Security, 2, 11-23. https://doi.org/10.21608/ jenvbs.2018.3479.1025

Amer, M. and Hashem, I. (2018) Impact of Some Soil Amendments on Properties and Productivity of Salt Affected Soils at Kafr El-Sheikh Governorate. Egy. J. Soil Sci. 58, 177-191. https://doi.org/10.21608/ ejss.2018.2356.1148

Amer, M., Abou El Soud, H., Rashad, S. and Gaiza, S. (2020) Contribution of management of irrigation water and organic application in improving some soil properties and its water productivity of sugar beet and cotton. Env. Biodiv. Soil Security, 4, 5-10. https://doi.org/10.21608/jenvbs.2020.24121.1082

Anand, A.K., Prasad, V. and Alam, M. (2015) Physicochemical characterization of Usar soil and its natural reclamation by cyanobacteria. J. Chem. Chem. Sci. 5, 145-152.

Apte, S.K. and Thomas, J. (1997) Possible amelioration of coastal soil salinity using halotolerant nitrogenfixing cyanobacteria. Plant Soil, 189, 205-211. https://doi.org/10.1023/A:1004291830391

Aubriot, L.and Bonilla, S. (2012) Rapid regulation of phosphate uptake in freshwater cyanobacterial blooms. Aquat. Microb. Ecol. 67, 251-263. https:// doi.org/10.3354/ame01596 HYPERLINK "https:// doi.org/10.3354/ame01596"

Bailey, J.S. (1995) Liming and nitrogen efficiency: Some effects of increased calcium supply and increased soil $\mathrm{pH}$ on nitrogen recovery by perennial ryegrass. Commun. Soil Sc. Plant Anal. 26, 7-8. 1233-1246, https://doi.org/ HYPERLINK "https:// doi.org/10.1080/00103629509369366"10.1080/00 103629509369366.

Bassouny, M. and Abbas, M. (2019) Role of Biochar in Managing the Irrigation Water Requirements of Maize Plants: the Pyramid Model Signifying the Soil Hydro-physical and Environmental Markers. Egy. J. Soil Sci. 59, 99-115. https://doi. 
org/10.21608/ejss.2019.9990.1252

Berry, S., Esper, B., Karandashova, I., Teuber, M., Elanskaya, I., Rögner, M. and Hagemann, M. (2003) Potassium uptake in the unicellular cyanobacterium Synechocystis sp. strain PCC 6803 mainly depends on a Ktr-like system encoded by slr1509 (ntpJ). FEBS Letters. 548, 53-58. https://doi.org/10.1016/ S0014-5793(03)00729-4

Cameron H.J. and Julian G.R., 1988. Utilisation of hydroxyapatite by cyanobacteria as their sole source of phosphate and calcium. Plant Soil 109, 123-124. https://doi.org/10.1007/BF02197589

Cao, J., Lompo, D.JP., Stenchly, K., Haering, V., Marchner, B. and Buerkert, A. (2019) Gypsum amendment to soil and plants affected by sodic alkaline industrial wastewater irrigation in Urban Agriculture of Ouagadougou, Burkina Faso. Water Air Soil Pollut. 230, 282. https://doi.org/10.1007/ $\underline{\text { s11270-019-4311-x }}$

Chaganti, V.N., Crohn, D.M. and Šimůnek, J. (2015) Leaching and reclamation of a biochar and compost amended saline-sodic soil with moderate SAR reclaimed water. Agri. Water Manag. 158, 255265, https://doi.org/10.1016/j.agwat.2015.05.016.

Chávez-García, E. and Siebe, C. (2019) Rehabilitation of a highly saline-sodic soil using a rubble barrier and organic amendments. Soil Till. Res. 189, 176188, https://doi.org/10.1016/j.still.2019.01.003.

Checchetto, V., Segalla, A., Allorent, G., Rocca, N.L., Leanza, L., Giacometti, G.M., Uozumi, N., Finazzi, G., Bergantino, E. and Szabò, I. (2012) Thylakoid potassium channel is required for efficient photosynthesis in cyanobacteria. Proc Natl Acad Sci USA 109 (27), 11043-11048. https:// doi.org/10.1073/pnas.1205960109

Du, X.L., Creed, I.F., Sorichetti, Charles, R.J. and Trick, G. (2019) Cyanobacteria biomass in shallow eutrophic lakes is linked to the presence of ironbinding ligands. Can J Fish Aquat Sci 76, 17281739, https://doi.org/10.1139/cjfas-2018-0261

El-Akhdar, I., El-Sheekh, M., Allam, N., Kamal, F., Abou-Shanab, R.and Staehelin, C. (2019) The potential use of microbial inocula for improving wheat productivity in saline soils. Env. Biodiv. Soil Security 3, 131-146. https://doi.org/10.21608/ jenvbs.2019.13580.1062

Elcossy, S.A.E., Abbas, M.H.H., Farid, I.M., Beheiry, G.G.S., Abou Yuossef, M.F., Abbas, H.H., Abdelhafez, A.A.and Mohamed, I. (2020) Dynamics of soil organic carbon in Typic Torripsamment soils irrigated with raw effluent sewage water. Environ. Sci. Pollut. Res. Int. 27, 8188-8198. https://doi. org/10.1007/s11356-019-07526-4.

Eletr, W.M.T.; Ghazal, F.M.; Mahmoud, A.A. and Yossef, G.H. (2013) Responses of wheat-rice cropping system to cyanobacteria inoculation and different soil conditioners sources under saline soil. Nature and Science 11, 118-129. www.dx.doi.org > marsnsj111013

Elloumi, N., Zouari, M., Chaari, L., Abdallah, F.B., Woodward, S. and Kallel, M. (2015) Effect of phosphogypsum on growth, physiology, and the antioxidative defense system in sunflower seedlings. Environ Sci Pollut Res 22, 14829-14840. https://doi.org/10.1007/s11356-015-4716-z

El-Naqme, K., El-Dissoky, R. and Aiad, M. (2019). Impact of Green Manure, Mineral and Bio Fertilizers on Soil Fertility, Onion-maize productivity and N-use efficiency. Env. Biodiv. Soil Security, 3, 11-28. https://doi.org/10.21608/ jenvbs.2019.7507.1051

El-Ramady H., Alshaal T., Yousef, S., Elmahdy, S., Faizy, S.E.-D., Amer, M., El-Din, H.S., ElGhamry, A.M., Mousa,A.A., Prokisch, J. and Senesi, N. (2019b) Soil Fertility and Its Security. In: El-Ramady H., Alshaal T., Bakr N., Elbana T., Mohamed E., Belal AA. (Eds) The Soils of Egypt. World Soils Book Series. Springer, Cham pp $137-$ 157. https://doi.org/10.1007/978-3-319-95516-2_8

El-Ramady, H., Abowaly, M., Elbehiry, F., Omara, A., Elsakhawy, T., Mohamed, S., Belal, A., Elbasiouny, H. and Abdalla, Z. (2019a). Stressful environments and sustainable soil management: A case study of Kafr El-Sheikh, Egypt. Env. Biodiv. Soil Security, 3, 193-213. https://doi.org/10.21608/ jenvbs.2019.17750.1070

Farid, I., Abbas, M. and El-Ghozoli, A. (2018) Implications of humic, fulvic and K-humate extracted from each of compost and biogas manures as well as their teas on faba bean plants grown on a Typic Torripsamment soil and emissions of soil $\mathrm{CO}_{2}$. Egy. J. Soil Sci. 58, 275-289. https://doi. org/10.21608/ejss.2018.3386.1168

Farid, I.M., Abbas, M.H.H. and Mustafa, E.F. (2014) Rationalizing the use of water of salinity hazards for irrigating maize grown in a saline sodic soil. Egy. J. Soil Sci. 54, 163-175. https://doi. org/ HYPERLINK "https://dx.doi.org/10.21608/ ejss.2014.131”10.21608/ejss.2014.131 
Favaretto, N., Norton, L.D., Johnston, C.T., Bigham, J. and Sperrin, M. (2012) Nitrogen and phosphorus leaching as affected by gypsum amendment and exchangeable calcium and magnesium. Soil Sci. Soc. Am. J. 76, 575-585. https://doi.org/10.2136/ sssaj2011.0223

Fu, F.X., Zhang, Y., Bell, P.R.F. and Hutchins, D.A. (2005) Phosphate uptake and growth kinetics of Trichodesmium (cyanobacteria) isolates from the north Atlantic ocean and the great barrier reef, Australia. J. Phycol. 41, 62-73. https://doi. org/ HYPERLINK "https://doi.org/10.1111/ j.1529-8817.2005.04063.x”10.1111/j.15298817.2005.04063.x

Fuchsman, C.A., Palevsky, H.I., Widner, B., Duffy, M., Carlson, M.C.G., Neibauer, J.A., Mulholland, M.R., Keil, R.G.,Devol, A.H. and Rocap, G. (2019) Cyanobacteria and cyanophage contributions to carbon and nitrogen cycling in an oligotrophic oxygen-deficient zone. ISME J. 13, 2714-2726 (2019). https://doi.org/10.1038/s41396-019-0452-6

Green, T.G.A., Sancho, L.G., Pintado, A., Saco, D., Martín, S., Arróniz-Crespo, M., Casermeiro, M.A., de la Cruz Caravaca, M.T., Cameron, S. and Rozzi, R. (2017) Sodium chloride accumulation in glycophyte plants with cyanobacterial symbionts, AoB PLANTS, 9 (6), plx053, https://doi. org/10.1093/aobpla/plx053

Guo, G., Araya, K., Jia, H., Zhang, Z., Ohomiya, K. and Matsuda, J. (2006) Improvement of saltaffected soils, Part 1: Interception of capillarity. Biosyst Eng. 94, 139-150. https://doi.org/10.1016/j. biosystemseng.2006.01.012.

Helmi, M.Y., Farid, I.M., Khalefa, A.M. and Abbas, M.H.H. (2018) The Feasibility of using microbial, organic and mineral amendments for ameliorating a saline-sodic soil and their implications on the productivity of sugar beet and rice grown thereon. Annal. Agric. Sci. Moshtohor 56, 799-810.

Jha, M., Prasad, A. and Misra, S. (2004) Influence of source of organics and soil organic matter content on cyanobacterial nitrogen fixation and distributional pattern under different water regimes. World J. Microbiol. Biotechnol. 20, 673-677. https://doi. org/10.1007/s11274-004-2157-9

Kamel, G., Noufal, E., Farid, I., Abdel-Aziz, S. and Abbas, M. (2016) Alleviating salinity and sodicity by adding some soil amendments. J. Soil Sci. Agri. Eng. 7, 389-395. https://doi.org/10.21608/ jssae.2016.39666.
Kaya, C., Kirnak,H. and Higgs, D. (2001) Enhancement of growth and normal growth parameters by foliar application of potassium and phosphorus in tomato cultivars grown at high $(\mathrm{NaCl})$ salinity, $J$ Plant Nutr $24 \quad$ (2), 357-367, https://doi.org/ HYPERLINK "https://doi.org/10.1081/PLN100001394"10.1081/PLN-100001394

Khan, H. R., Ahmed, I.U. and Blume, H. (1996) Effects of gypsum and $\mathrm{Zn}$ on uptake ratios of $\mathrm{Na}$, $\mathrm{K}$ and growth-yield of rice grown on a coastal saline soil. Z. Pflanzenernaehr. Bodenk. 159, 351-356. https://doi.org/ HYPERLINK "https:// doi.org/10.1002/jpln.1996.3581590407”10.1002/ jpln.1996.3581590407

Klute, A. (1986) Part 1. Physical and mineralogical methods .ASA-SSSA-Agronomy, Madison, Wisconsin USA.

Larbi, A., Kchaou, H., Gaaliche, B., Gargouri, K., Boulal, H. and Morales, F. (2020) Supplementary potassium and calcium improves salt tolerance in olive plants. Sci. Horti. 260, 108912, https://doi. org/10.1016/j.scienta.2019.108912.

Lei, Y., Song, B., Saakes, M., van der Weijden, R.D. and Buisman, C.J.N. (2018) Interaction of calcium, phosphorus and natural organic matter in electrochemical recovery of phosphate. Water Res. 142, 10-17. https://doi.org/10.1016/j. watres.2018.05.035.

Li, H., Zhao, Q. and Huang, H. (2019a) Current states and challenges of salt-affected soil remediation by cyanobacteria. Sci. Total Environ. 669, 258-272. https://doi.org/10.1016/j.scitotenv.2019.03.104.

Li, Y., Haynes, R.J., Chandrawana, I. and Zhou, Y.F. (2019b) Growth of Rhodes grass and leaching of ions from seawater neutralized bauxite residues after amendment with gypsum and organic wastes. J. Environ. Manag. 231, 596-604. https://doi. org/10.1016/j.jenvman.2018.10.083.

Lowther, J.R. (1980) Use of a single sulphuric acid hydrogen peroxide digest for the analysis of Pinus radiata needles. Commun. Soil Sci. Plant Anal. 11, 175-188. https://doi.org/ HYPERLINK "https:// doi.org/10.1080/00103628009367026"10.1080/00 103628009367026

Mahdavi, S.M.and Fujimaki, H. (2019) Soil salinity resistance effect on evaporation. Euras. Soil Sci. 52, 526-534. https://doi.org/10.1134/ S1064229319050089

Makoi, J.H.J.R. and Verplancke, H. (2010) Effect 
of gypsum placement on the physical chemical properties of a saline sandy loam soil. Aust. J. Crop Sci. 4, 556-563.

Masoud, A.A., Koike, K., Atwia, M.G., El-Horiny, M.M.and Gemail, K.S. (2019) Mapping soil salinity using spectral mixture analysis of landsat 8 OLI images to identify factors influencing salinization in an arid region, Inter. J. Appl. Earth Observ. Geoinform. 83, 101944, https://doi.org/10.1016/j. jag.2019.101944.

Menzies Pluer, E.G., Schneider, R., Morreale, S., Liebig, M.A., Li, J., Li, C.X.and Walter, M.T. (2020) Returning degraded soils to productivity: an examination of the potential of coarse woody amendments for improved water retention and nutrient holding capacity. Water Air Soil Pollut 231, 15. https://doi.org/10.1007/s11270-019-4380-x

Misra, A.N., Srivastava, A. and Strasser, R.J. (2001) Utilization of fast chlorophyll a fluorescence technique in assessing the salt/ion sensitivity of mung bean and Brassica seedlings. J. Plant Physiol. 158, 1173-1181. https://doi.org/10.1078/ S0176-1617(04)70144-3.

Munns, R. and Tester, M. (2008) Mechanisms of salinity tolerance. Ann. Rev. Plant Biol. 59, 651681. https://doi.org/10.1146/annurev. arplant.59.032607.092911

Murtaza, B., Murtaza, G., Sabir, M., Owens, G., Abbas, G., Imran, M. and Shah, G.M. (2017) Amelioration of saline-sodic soil with gypsum can increase yield and nitrogen use efficiency in rice-wheat cropping system, Arch Agron Soil Sci 63 (9), 1267-1280, https://doi.org/ HYPERLINK "https://doi.org/10.1 080/03650340.2016.1276285"10.1080/03650340. 2016.1276285

Murukesan, G., Lynch, F., Allahverdiyeva, Y. and Kosourov, S. (2019) Acclimation responses of immobilized N2-fixing heterocystous cyanobacteria to long-term $\mathrm{H}_{2}$ photoproduction conditions: carbon allocation, oxidative stress and carotenoid production. J. Appl. Phycol. 31, 131-143. https:// doi.org/10.1007/s10811-018-1535-x

Negm, M. E., El- Kallawy, W. and Hefeina, A. (2019). Comparative study on rice germination and seedling growth under salinity and drought stresses. Env. Biodiv. Soil Security, , 3, 109-117. https://doi. org/10.21608/jenvbs.2019.11933.1058

Nisha, R., Kiran, B., Kaushik, A. and Kaushik, C.P. (2018) Bioremediation of salt affected soils using cyanobacteria in terms of physical structure, nutrient status and microbial activity. Int. J. Environ. Sci. Technol. 15, 571-580 https://doi. org/10.1007/s13762-017-1419-7

Nõges, T., Laugaste, R., Nõges, P.and Tõnno, I. (2008) Critical N:P ratio for cyanobacteria and $\mathrm{N}_{2}$-fixing species in the large shallow temperate lakes Peipsi and Võrtsjärv, North-East Europe. Hydrobiologia 599, 77-86. https://doi. org/10.1007/s10750-007-9195-x

Ouda S. and Zohry A.E.H. (2020) Water Scarcity Leads to Food Insecurity. In: Deficit Irrigation. Springer, Cham,pp 1-13. https://doi.org/10.1007/978-3-03035586-9 1

Page, A.L., Miller, R.H.and Keeney, D.R. (1982) Methods of soil analysis. ASA-SSSA.Agronomy, Madison, USA.

Panda A. and Parida A.K. (2019) Development of Salt Tolerance in Crops Employing Halotolerant Plant Growth-Promoting Rhizobacteria Associated with Halophytic Rhizosphere Soils. In: Kumar M., Etesami H., Kumar V. (eds) Saline Soil-based Agriculture by Halotolerant Microorganisms. Springer, Singapore, pp 75-10. https://doi. org/10.1007/978-981-13-8335-94

Pandey, K.D., Shukla, P.N., Giri, D.D. and Kashyap, A.K. (2005) Cyanobacteria in alkaline soil and the effect of cyanobacteria inoculation with pyrite amendments on their reclamation. Biol Fertil Soil. 41, 451-457. https://doi.org/10.1007/s00374-0050846-7

Pavani, K., Shanmugam, P.M.and Baskar, M. (2019) Effect of gypsum and organic amendments on rice yield in a sodic soil. Agri. Res. J. 56, 226-230. https://doi.org/ HYPERLINK "http://dx.doi.org/10.5958/2395146 X.2019.00035.8”10.5958/2395146X.2019.00035.8

Qiu, B., Zhang, A., Zhou, W., Wei, J., Dong, H. and Liu, Z. (2004) Effects of potassium on the photosynthetic recovery of Nostoc flagelliforme (cyanobacteria) During rehydration. J. Phycol. 40, 323-332. https://doi.org/ HYPERLINK "https://doi. org/10.1111/j.1529-8817.2004.03152.x”10.1111/ j.1529-8817.2004.03152.x

Rady, M.M., Taha, S.S. and Kusvuran, S. (2018) Integrative application of cyanobacteria and antioxidants improves common bean performance under saline conditions. Sci Hortic 
(Amsterdam) 233, 61-69._https://doi.org/10.1016/j. scienta.2018.01.047.

Rasouli, F., Pouya, A.K. and Karimian, N. (2013) Wheat yield and physico-chemical properties of a sodic soil from semi-arid area of Iran as affected by applied gypsum, Geoderma, 193-194, 246-255. https://doi.org/10.1016/j.geoderma.2012.10.001

Rousk, J., Elyaagubi, F.K., Jones, D.L. and Godbold, D.L. (2011) Bacterial salt tolerance is unrelated to soil salinity across an arid agroecosystem salinity gradient. Soil Biol Biochem 43, 1881-1887. https:// doi.org/10.1016/j.soilbio.2011.05.007.

Selem, E. (2019) Physiological effects of Spirulina platensis in salt stressed Vicia faba L. plants. Egy. J. Botany. 59, 185-194. https://doi.org/10.21608/ ejbo.2018.3836.1178

Shahane, A.A., Shivay, Y.S., Prasanna, R. and Kumar, D. (2019) Nitrogen nutrition and use efficiency in rice as influenced by crop establishment methods, cyanobacterial and phosphate solubilizing bacterial consortia and zinc fertilization. Commun. Soil Sci. Plant Anal. 50, 1487-1499. https://doi.org/ HYPERLINK "https://doi.org/10.1080/00103624 .2019.1626876”10.1080/00103624.2019.1626876

Singh N.K. and Dhar D.W. (2010) Cyanobacterial Reclamation of Salt-Affected Soil. In: Lichtfouse E. (eds) Genetic Engineering, Biofertilisation, Soil Quality and Organic Farming. Sus. Agri. Rev. vol 4. Springer, Dordrecht, pp 243-275. https://doi. org/10.1007/978-90-481-8741-6_9

Singh, J.S., Kumar, A., Rai, A.N., Singh, D.P. (2016a) Cyanobacteria: A Precious Bio-resource in Agriculture, Ecosystem, and Environmental Sustainability. Front. Microbial. 7, 529. https://doi. org/10.3389/fmicb.2016.00529

Singh, K., Mishra, A.K., Singh, B., Singh, R.P. and Patra, D.D. (2016b) Tillage effects on crop yield and physicochemical properties of sodic soils. Land Degrad. Develop. 27, 223- 230. https:// doi.org/ HYPERLINK "https://doi.org/10.1002/ ldr.2266"10.1002/ldr.2266.

Singh, V.and Singh, D. (2018) Cyanobacteria modulated changes and its impact on bioremediation of salinealkaline soils. Bangl. J. Botany. 44, 653-658. https://doi.org/10.3329/bjb.v44i4.38646
Sparks, D.L., Page, A.L., Helmke, P.A., Loeppert, R.H., Soltanpour, P.N., Tabatabai, M.A., Johnston, C.T.and Sumner, M.E. (1996) Methods of Soil Analysis Part 3-Chemical Methods, 5.3, SSSA Book Series, Madison, WI.

Swapnil, P.and Rai, A.K. (2018) Physiological responses to salt stress of salt-adapted and directly salt $\left(\mathrm{NaCl}\right.$ and $\mathrm{NaCl}+\mathrm{Na}_{2} \mathrm{SO}_{4}$ mixture)stressed cyanobacterium Anabaena fertilissima. Protoplasma 255, 963-976. https://doi. org/10.1007/s00709-018-1205-5

Syed-Omar, S.R.and Sumner, M.E. (1991) Effect of gypsum on soil potassium and magnesium status and growth of alfalfa. Commun. Soil Sci. Plant Anal. 22, 19-20, 2017-2028. https://doi.org/ HYPERLINK "https://doi.org/10.1080/001036291 09368554"10.1080/00103629109368554

Tang, D., Shi, S., Li, D., Hu, C. and Liu, Y. (2007) Physiological and biochemical responses of Scytonema javanicum (cyanobacterium) to salt stress. J. Arid Environ. 71, 312-320., https://doi. org/10.1016/j.jaridenv.2007.05.004.

Thomas, J., Apte, S.K. J. Biosci. (1984) Sodium requirement and metabolism in nitrogen-fixing cyanobacteria. J. Biosci. 6, 771-794.

Uusitalo, R.,Ylivainio, K., Hyväluoma, J., Rasa, K., Kaseva, J., Nylund, P., Pietola, L. and Turtola, E. (2012) The effects of gypsum on the transfer of phosphorus and other nutrients through clay soil monoliths. Agri. Food Sci. 21, 260-278.

Wang, J., Yuan, G., Lu, J., Wu, J. and Wei, J. (2019) Variation of salts and available nutrients in saltaffected soil during leaching process under the influence of organic ameliorators. Chem. Ecol. 36 (3), 256-269.

Wein, T., Picazo, D.R., Blow, F., Woehle, C., Jami, E., Reusch, T.B.H., Martin, W.F. and Dagan, T. (2019) Currency, exchange, and inheritance in the evolution of symbiosis. Tren. Microbiol. 27, 836849. https://doi.org/10.1016/j.tim.2019.05.010

Wuddivira, M.N. and Camps-Roach, G. (2007) Effects of organic matter and calcium on soil structural stability. Eur. J. Soil Sci. 58, 722-727. 